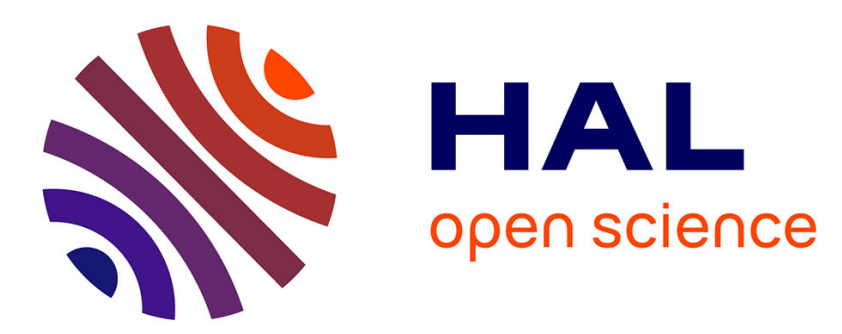

\title{
The recorded economic costs of alien invasive species in Italy
}

Phillip J Haubrock, Ross N Cuthbert, Elena Tricarico, Christophe Diagne, Franck Courchamp, Rodolphe E Gozlan

\section{- To cite this version:}

Phillip J Haubrock, Ross N Cuthbert, Elena Tricarico, Christophe Diagne, Franck Courchamp, et al.. The recorded economic costs of alien invasive species in Italy. NeoBiota, 2021, 67, pp.247 - 266. 10.3897/neobiota.67.57747 . hal-03410329

\section{HAL Id: hal-03410329 \\ https://hal.science/hal-03410329}

Submitted on 31 Oct 2021

HAL is a multi-disciplinary open access archive for the deposit and dissemination of scientific research documents, whether they are published or not. The documents may come from teaching and research institutions in France or abroad, or from public or private research centers.
L'archive ouverte pluridisciplinaire $\mathbf{H A L}$, est destinée au dépôt et à la diffusion de documents scientifiques de niveau recherche, publiés ou non, émanant des établissements d'enseignement et de recherche français ou étrangers, des laboratoires publics ou privés. 


\title{
The recorded economic costs of alien invasive species in Italy
}

\author{
Phillip J. Haubrock ${ }^{1,2^{*}}$, Ross N. Cuthbert ${ }^{3,4^{*}}$, Elena Tricarico ${ }^{5}$, \\ Christophe Diagne ${ }^{6}$, Franck Courchamp ${ }^{6}$, Rodolphe E. Gozlan ${ }^{7,8}$
}

I Senckenberg Research Institute and Natural History Museum Frankfurt, Department of River Ecology and Conservation, 63571 Gelnhausen, Germany 2 University of South Bohemia in České Budèjovice, Faculty of Fisheries and Protection of Waters, South Bohemian Research Center of Aquaculture and Biodiversity of Hydrocenoses, Zátiš̌ 728/II, 38925 Vodñany, Czech Republic 3 GEOMAR Helmholtz-Zentrum für Ozeanforschung Kiel, 24105 Kiel, Germany 4 School of Biological Sciences, Queen's University Belfast, 19 Chlorine Gardens, Belfast, BT9 5DL, Northern Ireland, UK 5 University of Florence, Department of Biology, Via Madonna del Piano 6, 50019 Sesto Fiorentino (FI), Italy 6 School of Natural and Environmental Sciences, Newcastle University, NE1 7RU, UK 7 Université Paris-Saclay, CNRS, AgroParisTech, Ecologie Systématique Evolution, 91405, Orsay, France 8 ISEM, Univ Montpellier, CNRS, EPHE, IRD, Montpellier, France

Corresponding authors: Phillip J. Haubrock (phillip.haubrock@senckenberg.de); Elena Tricarico (elena.tricarico@unifi.it)

Academic editor: R. Zenni | Received 19 August 2020 | Accepted 11 December 2020 | Published 29 July 2021

Citation: Haubrock PJ, Cuthbert RN, Tricarico E, Diagne C, Courchamp F, Gozlan RE (2021) The recorded economic costs of alien invasive species in Italy. In: Zenni RD, McDermott S, García-Berthou E, Essl F (Eds) The economic costs of biological invasions around the world. NeoBiota 67: 247-266. https://doi.org/10.3897/neobiota.67.57747

\begin{abstract}
Whilst the ecological impacts of invasion by alien species have been well documented, little is known of the economic costs incurred. The impacts of invasive alien species on the economy can be wide-ranging, from management costs, to loss of crops, to infrastructure damage. However, details on these cost estimates are still lacking, particularly at national and regional scales. In this study, we use data from the first global assessment of economic costs of invasive alien species (InvaCost), where published economic cost data were systematically gathered from scientific and grey literature. We aimed to describe the economic cost of invasions in Italy, one of the most invaded countries in Europe, with an estimate of more than 3,000 alien species. The overall economic cost of invasions to Italy between 1990 and 2020 was estimated at US\$ 819.76 million (EUR€ 704.78 million). This cost was highest within terrestrial habitats, with considerably fewer costs being exclusively associated with aquatic habitats and management methods, highlighting a bias within current literature. There was also a clear indication of informational gaps, with only
\end{abstract}

* Contributed equally as the first authors.

Copyright Phillip J. Haubrock et al. This is an open access article distributed under the terms of the Creative Commons Attribution License (CC BY 4.0), which permits unrestricted use, distribution, and reproduction in any medium, provided the original author and source are credited. 
15 recorded species with costs. Further, we observed a tendency towards particular taxonomic groups, with insect species accounting for the majority of cost estimates in Italy. Globally, invasion rates are not slowing down and the associated economic impact is thus expected to increase. Therefore, the evaluation and reporting of economic costs need to be improved across taxa, in order to mitigate and efficiently manage the impact of invasions on economies.

\section{Abstract in Italian}

I costi economici riportati per le specie aliene invasive in Italia. Sono ancora poco noti i costi economici causati dalle invasioni biologiche, mentre gli impatti ecologici sono stati ben documentati. Gli impatti delle specie aliene invasive sull'economia possono essere vari: si va dai costi di gestione, alla perdita dei raccolti e ai danni alle infrastrutture. Tuttavia, non ci sono ancora dettagli su questi costi stimati, in particolare a livello nazionale e regionale. In questo studio, vengono utilizzati i dati della prima valutazione globale sui costi economici delle specie aliene invasive (InvaCost), dove i dati pubblicati sui costi economici sono stati raccolti dalla letteratura scientifica e grigia. L'obiettivo è stato descrivere i costi economici delle invasioni biologiche in Italia, uno dei paesi più invasi in Europa con oltre 3000 specie aliene stimate. Nel complesso, il costo economico stimato delle invasioni in Italia tra il 1990 e il 2020 si aggira sugli 819.76 milioni US\$ (che corrispondono a 704.78 milioni di euro). Il costo maggiore è stato rilevato per gli habitat terrestri, mentre molto pochi sono stati i costi trovati associati strettamente agli habitat acquatici e alla gestione, sottolineando una disparità nella letteratura odierna. Si è evidenziato anche una mancanza di informazioni, con costi riportati solo per 15 specie. Inoltre, è stata osservata una preponderanza di dati per alcuni gruppi tassonomici: gli insetti sono responsabili della maggior parte dei costi stimati in Italia. A livello globale, i tassi di invasione non stanno rallentando e ci si aspetta, quindi, che gli impatti economici associati crescano. Di conseguenza, è necessario migliorare la valutazione e riportare i costi economici tra i vari taxa per mitigare e gestire in maniera efficace gli impatti delle invasioni sulle attività economiche.

\section{Abstract in Deutsch}

Die erfassten wirtschaftlichen Kosten gebietsfremder invasiver Arten in Italien. Während die ökologischen Auswirkungen der Invasion gebietsfremder Arten gut dokumentiert sind, ist wenig über die wirtschaftlichen Kosten bekannt. Die Auswirkungen invasiver gebietsfremder Arten auf die Wirtschaft können weitreichend sein, von Verwaltungskosten über Ernteverluste bis hin zu Infrastrukturschäden. Einzelinformationen zu diesen Kostenschätzungen fehlen jedoch noch, insbesondere auf nationaler und regionaler Ebene. In dieser Studie verwenden wir Daten aus der ersten globalen Datenbank der wirtschaftlichen Kosten invasiver gebietsfremder Arten (InvaCost), bei der veröffentlichte wirtschaftliche Kostendaten systematisch aus wissenschaftlicher und grauer Literatur gesammelt wurden. Wir wollten die wirtschaftlichen Kosten von Invasionen in Italien, einem der am stärksten von biologischen Invasionen beeinflussten Länder Europas (geschätzt mehr als 3.000 gebietsfremden Arten) beschreiben. Die gesamtwirtschaftlichen Kosten von Invasionen in Italien zwischen 1990 und 2020 wurden auf 819,76 Mio. USD (704,78 Mio. EUR) geschätzt. Diese Kosten waren in terrestrischen Lebensräumen am höchsten, wobei erheblich weniger Kosten ausschließlich mit aquatischen Lebensräumen und Bewirtschaftungsmethoden verbunden waren, was auf eine Verzerrung in der aktuellen Literatur hinweist. Es gab auch deutliche Hinweise auf Informationslücken, da Kosten nur für 15 Arten registriert waren. Darüber hinaus beobachteten wir eine Tendenz zu bestimmten taxonomischen Gruppen, wobei Insektenarten den größten Teil der Kostenschätzungen in Italien ausmachen. Die Raten biologischer Invasionen verlangsamen sich weltweit nicht und die damit verbundenen wirtschaftlichen Auswirkungen werden voraussichtlich zunehmen. Daher muss die Bewertung und Berichterstattung der wirtschaftlichen Kosten in allen Taxa verbessert werden, um die Auswirkungen von Invasionen auf die Volkswirtschaften abzuschwächen und effizient zu steuern. 


\begin{abstract}
Spanish
Los costos económicos registrados de las especies exóticas invasoras en Italia. Poco se conoce sobre los costes económicos que provocan las especies invasoras, mientras que los impactos ecológicos se caracterizan por estar bien documentados. Los impactos económicos que provocan las especies invasoras pueden provenir de una amplia gama, desde costes de manejo, pérdidas en cultivos, hasta daños a la infraestructura. Sin embargo, los detalles sobre los costes aún se desconocen, particularmente a una escala regional y nacional. En el presente estudio, se emplearon datos de la primera evaluación global de los costes económicos de las especies invasoras (InvaCost), donde se publicaron datos económicos colectados sistemáticamente de literatura científica y literatura gris. El objetivo del presente estudio es describir los costes económicos de las especies invasoras en Italia, uno de los países con la mayor presencia de invasiones en Europa, con un estimado de más de 3,000 especies exóticas presentes. Los costes económicos generales se estimaron en US \$817.76 millones (EUR€ 704.78 millones) entre 1990 y 2020 en Italia. Los costes se observaron mayores entre los hábitats terrestres y los métodos de manejo, destacando una desviación entre los datos presentados en la literatura actual. Se observó también una clara evidencia de vacíos de información, donde solo 15 especies se reportaron en los costes. Adicionalmente, se observó una tendencia hacia algunos grupos taxonómicos en particular, en donde las especies de insectos presentaron la mayoría de los datos para estimar los costes de sus invasiones en Italia. Mundialmente, las tasas de invasión no están disminuyendo, por lo que se espera que los impactos económicos se eleven. Asimismo, la evaluación y reporte de los costes económicos requieren de mejores estimaciones entre los taxa, para una mitigación y manejo eficiente del impacto sobre la economía de las especies invasoras.
\end{abstract}

\title{
Keywords
}

biodiversity, ecosystem services, Europe, InvaCost, resource damages, socioeconomic indicators

\section{Introduction}

Despite an increasing number of indicators, targets and alarming reports on the rapid decline of biodiversity worldwide, limited economic resources have been allocated to tackle the ongoing erosion of biodiversity (Gren et al. 2009; Hulme et al. 2009; Scalera 2010). Amongst the key drivers of biodiversity decline are the ecological impacts of invasive alien species (IAS) on native species and ecosystems (Malcolm and Markham 2000; Stigall 2010), with the spread of alien species showing no sign of abatement (Seebens et al. 2017). Alien species have been shown to be major drivers of extinction globally across multiple taxonomic groups and geographic regions, being the second most common threat associated with extinct species since AD 1500 (Bellard et al. 2016).

The ecological impacts of biological invasions have been well-described and reported in abundance in scientific literature (see Gurevich and Padilla 2004; Didham et al. 2005; Dick et al. 2017; Haubrock et al. 2021a). For example, plant invasions have been shown to have significant impacts at the species, community and ecosystem level, reducing the diversity and abundance of native assemblages (Vilà et al. 2011). In turn, impacts from groups, such as mammalian predators, have been shown to be particularly marked on native birds, mammals and reptiles, especially on islands (Doherty et al. 2016). However, relatively-few studies have synthesised impacts in monetary terms 
(Bradshaw et al. 2016; Diagne et al. 2020a, b), limiting economic quantifications of invasion costs. Indeed, reported economic costs of IAS are fragmented across habitats (e.g. terrestrial, aquatic), specific management actions (e.g. control, eradication) or activity sectors (e.g. agriculture, fisheries; Lovell et al. 2006; Marbuah et al. 2014). Accordingly, there is a distinct lack of comprehensive quantification regarding economic costs of invasive species across multiple systems and geographic regions. Characterising the cost of invasions at the national level, the main governance level at which budgets are established, is essential to provide basic economic elements necessary for states to implement internationally-binding regulations on biodiversity and to promote management actions towards IAS.

Despite some acknowledged methodological flaws (Holmes et al. 2009; Perrings 2011; Cuthbert et al. 2020), Pimentel's studies (Pimentel et al. 2000, 2005) have effectively raised awareness on the grossly underestimated costs associated with alien species introductions (Hensley 2012; Bradshaw et al. 2016). In these works, most of the costs related to invasive species were analysed for the United States. Therefore, invasion costs incurred in Europe have been understudied, despite Europe being a historic centre of globalisation (Reba et al. 2016), and, by virtue, a hub for alien species introductions. Nonetheless, Kettunen et al. (2009) estimated a total cost of approximately 12 billion Euro $(€)$ per year across Europe (Haubrock et al. 2021b). However, many of these cost estimations are untraceable (and thus potentially unreliable) and information at national scales has remained anecdotal at best. Such national-scale information is essential, as it is at this level that budgeting and decision-making are often made.

One particular example is Italy, which has been considered as one of the financial and cultural centres for the development of Europe (James and O'Rourke 2011), with a history of many alien species introductions (Occhipinti-Ambrogi 2002; Nunes et al. 2014, 2015; Tricarico et al. 2018). In total, the Global Register of Introduced and Invasive Species (GRIIS, Pagad et al. 2018; National Database on Alien Species, ISPRA) lists in excess of 3,000 known alien species in Italy, at present, with 15\% of those species considered invasive. These have occurred through various pathways, such as agriculture, angling or horticulture, to name only a few. As such, Italy is today referred to as a hotspot and gateway for several groups of invasive species (Occhipinti-Ambrogi 2002; Occhipinti-Ambrogi et al. 2011; Castaldelli et al. 2013; Nunes et al. 2014, 2015). In particular, aquatic ecosystems in Italy have been burdened with well-intentioned introduction efforts in support of recreational angling (Occhipinti-Ambrogi 2002; Gherardi et al. 2008; Gravili et al. 2010). This has led to the establishment of more than 150 freshwater aquatic species (at least 64 invertebrates and 48 vertebrates), reported in 2008 to contribute at least $2 \%$ of the inland-water fauna (Gherardi et al. 2008; Tricarico E. pers. comm.). In addition, approximately 165 alien marine species have been recorded along the 7,000 km long coastline, aided by increased, human-mediated habitat connectivity (Occhipinti-Ambrogi et al. 2010). In terrestrial ecosystems, at least 923 insect species taxa have been introduced (Inghilesi et al. 2013).

Despite these burgeoning numbers of high-impact invasions in Italy, cost data on the Italian economy are still scarce. The lack of cost quantifications impedes decisionmaking by policy-makers and stakeholders, owing to a distinct absence of an economic 
rationale for environmental priority actions. We hypothesise that these costs are substantial, although a considerable difference in costs amongst ecosystem types can be expected. Based on data from current literature, we synthesised and described, for the first time, the costs of invasions on the Italian economy. More particularly, we first aimed at depicting how these costs are distributed according to the a) invasive species or broader taxonomic groups (i.e. classes or orders), b) socioeconomic sectors, c) geographic regions and d) cost types, whilst examining the effects of habitat type within each of these descriptors. Second, we determined how the overall costs have changed since cost reporting began and whether these costs of invasions are depicting a particular trend over time.

\section{Methods}

To investigate the invasion costs on the Italian economy, we used cost data collected in the InvaCost database (2,419 entries; Diagne et al. 2020a, b) concerning the global costs of invasive species, based on published literature, enabling comprehensive quantification of costs associated with invasive species at various spatial and temporal scales. This updatable database was constructed, based on both published and grey literature and enables the most comprehensive cost quantifications associated with invasive species. All the methodological procedures, from literature searches to data collation, have been detailed elsewhere (Diagne et al. 2020b; Angulo et al. 2021a). All cost entries were standardised to a common and up-to-date currency (US dollars (US\$) 2017). We complemented the data following two specific ways: on one hand, we have added cost data collected from non-English documents, including Italian (5,212 entries; Angulo et al. 2021a. https://doi.org/10.6084/m9.figshare.12928136). Further, we added supplementary cost data from new references containing cost information (ca. 2,300 entries; https://doi.org/10.6084/m9.figshare.12928145.v1).

The period of estimation across reported costs varied considerably, spanning periods of several months to several years. For the purpose of the analysis and to derive the total cumulative cost of invasions over time, we considered the duration time (i.e. number of years) over which each cost occurred. For this purpose, we defined the duration of each cost entry. We based this on the difference between the starting ("Probable starting year low margin" column) and ending ("Probable ending year low margin" column) years of the reported costs. When no period of impact was specified in one and/or the other column(s), we counted only a single year unless the authors were certain that the costs had been repeated up to a certain year. The obtained figures corresponded to the total cumulative cost along a defined period for each entry.

From the full database, we identified cost entries related to the Italian economy by filtering data using the 'Official country' column. In addition to the already available information present in the database, we added six further cost records, summarised in the work of one of the authors (Tricarico et al. 2018) and sent them to invacost@updates.fr to be integrated into the InvaCost database. The final dataset can be found in Suppl. material 1. Finally, the invasion costs were specifically estimated from all entries 
according to method reliability, i.e. indicating the reliability of cost estimates, based on the type of publication and method of estimation. Estimates in peer-reviewed publications or official reports or with documented, repeatable and/or traceable methods were designated as High reliability; all other estimates were designated as Low reliability (Diagne et al. 2020b); the taxonomic group ('Class', 'Order' and 'Species' columns); activity sector (the activity, societal or market sector that was impacted by the cost; 'Impacted sector' column, see Suppl. material 2); invaded habitat ('Environment' column); and lastly the cost type ('Type of cost' column) by grouping costs according to the categories: (a) Damage referring to damages or losses incurred from invasion (e.g. costs for damage repair, resource losses, medical care), (b) Management comprising control-related expenditure (e.g. monitoring, prevention, management, eradication) and money spent on education, research and maintenance costs, (c) Mixed including mixed damage and management costs (cases where reported costs were not clearly distinguished amongst cost types). In addition, for the purpose of investigating the costs in different habitats, we defined costs on wetlands and riparian zones generated by organisms that have an association with both terrestrial and aquatic environments, as Semi-aquatic. For costs that were estimated at a spatial scale below the Country level within Italy, we considered them in a finer-scale Regional analysis, using the 'Spatial scale' and 'Details' columns.

We estimated global average annual costs of invasive species in Italy represented in the InvaCost database by quantifying the temporal trends in cost accumulations. We performed these estimates for the period from 1990 to 2020. To investigate invasion costs in Italy over time and, hence, to identify whether costs are saturating over time or continuously increasing, we used the summarizeCosts function of the 'invacost' $\mathrm{R}$ package (Leroy et al. 2021). We thus determined decadal average costs since 1990, as well as the cumulative and average annual cost of that entire time period. Overall, this approach allowed for trends in raw data cost to be examined over time, corresponding to the impacted year when the cost was incurred.

\section{Results}

There were 50 economic cost entries ( 40 of which from the original InvaCost database) associated with Italy. After expansion, the collective 207 expanded database entries totalled US\$ 819.76 million between 1990 and 2020 (US\$ 26.44 million per year). From these, $76 \%$ of costs were actually realised (i.e. assigned to Observed category in the 'Implementation' column) and $97 \%$ of the total costs were considered as of High reliability ('Method reliability' column) and, thus, derived from peer-reviewed or traceable sources.

\section{Economic costs by taxonomic group}

A high proportion of the filtered database entries concerned invasive mammal species (number of expanded database entries $n=88$; US\$ 149.81 million, Table 1). Invasive 
Table I. List of invasive alien species entries with reported costs in Italy, alongside associated taxonomic groupings. Data sourced from the InvaCost database.

\begin{tabular}{|c|c|c|c|c|c|c|}
\hline Class & Order & Family & Genus & Species & Database entries & Cost in US\$ million \\
\hline \multirow[t]{6}{*}{ Insecta } & Diptera & Culicidae & Aedes & albopictus & 21 & 95.95 \\
\hline & & Lauxaniidae & Drosophila & suzukii & 7 & 20.27 \\
\hline & Hemiptera & Pentatomidae & Halyomorpha & halys & 1 & 3.40 \\
\hline & Coleoptera & Cerambycidae & Anoplophora & chinensis & 23 & 8.99 \\
\hline & & Curculionidae & Rhynchophorus & ferrugineus & 4 & 6.70 \\
\hline & & Chrysomelidae & Diabrotica & virgifera & 1 & 138.12 \\
\hline Plantae & Asterales & Asteraceae & Ambrosia & artemisiifolia & 5 & 344.80 \\
\hline \multirow[t]{4}{*}{ Mammalia } & Artiodactyla & Cervidae & Dama & dama & 6 & 0.38 \\
\hline & Rodentia & Muridae & Rattus & rattus & 1 & 2.34 \\
\hline & & Sciuridae & Sciurus & carolinensis & 1 & 0.02 \\
\hline & & Myocastoridae & Myocastor & coypus & 80 & 147.07 \\
\hline Secernentea & & Aphelenchidae & Bursaphelenchus & mucronatus & 13 & 26.91 \\
\hline Bivalvia & Myida & Dreissenidae & Dreissena & polymorpha & 11 & 0.37 \\
\hline \multirow[t]{2}{*}{ Malacostraca } & Amphipoda & Gammaridae & Dikerogammarus & villosus & 6 & 0.18 \\
\hline & Decapoda & Diverse & Diverse & Diverse & 27 & 24.27 \\
\hline
\end{tabular}

insects represented the second most reported class ( $\mathrm{n}=57$; US $\$ 273.42$ million), followed by invasive Malacostraca ( $\mathrm{n}=33$; US $\$ 24.45$ million). In turn, invasive plants $(\mathrm{n}=5)$ and invasive nematodes $(\mathrm{n}=13)$ had a combined overall cost of US\$ 371.72 million. Looking at specific orders, invasive Asterales contributed, with US\$344.80 million, the most to the cost burden, followed by invasive Coleoptera (US $\$ 153.81$ million), Rodentia (US\$ 149.43 million) and Diptera (US\$ 116.22 million). Taken together, all other orders accounted for less than US\$100.00 million (Table 1; Fig. 1).

\section{Economic costs by invaded habitat, sector and type}

Economic costs of invasions differed by invaded habitat type. Costs associated with impacts in terrestrial habitats summed to US\$ 647.88 million $(n=83)$, inferred to 12 taxa. From these, US\$ 480.51 million $(n=68)$ was classified as observed. Cost estimates associated with aquatic-only environments accumulated to just US\$24.82 million ( $\mathrm{n}=44)$, inferred only to Dikerogammarus villosus (US\$ 178.83 thousand; $\mathrm{n}$ = 6), Dreissena polymorpha (US\$ 368.38 thousand; $\mathrm{n}=11$ ) and further unspecified freshwater crayfish (US\$24.27 million; $\mathrm{n}=27$ ). Semi-aquatic habitats (mostly linked to the semi-aquatic coypu Myocastor coypus; Guichón et al. 2003) totalled US\$147.07 million $(\mathrm{n}=80)$.

The overall cost distribution across taxa, sectors and types is shown in Fig. 2. Overall, agriculture (US\$ 476.27 million; $\mathrm{n}=53$ ) and authorities-stakeholders (US\$ 65.37 million; $\mathrm{n}=69$ ) were the primarily impacted sectors, followed by costs associated with the health sector (US\$ 54.32 million; $\mathrm{n}=3$ ), forestry (US\$ 33.61 million; $\mathrm{n}=17$ ) and, lastly, public and social welfare (US\$ 14.97 million; $\mathrm{n}=12$ ) and the environment (US\$ 13.72 million; $n=6$ ). Mixed sectors (i.e. costs that were not specifically assigned to one sector) contributed an additional US\$ 161.61 million $(\mathrm{n}=47)$. The costs of invasive species in terrestrial habitats were predominantly associated with agriculture (US\$ 453.79 million; $\mathrm{n}=21$ ), mixed sectors (US\$ 84.89 million; $\mathrm{n}=11$ entries), 


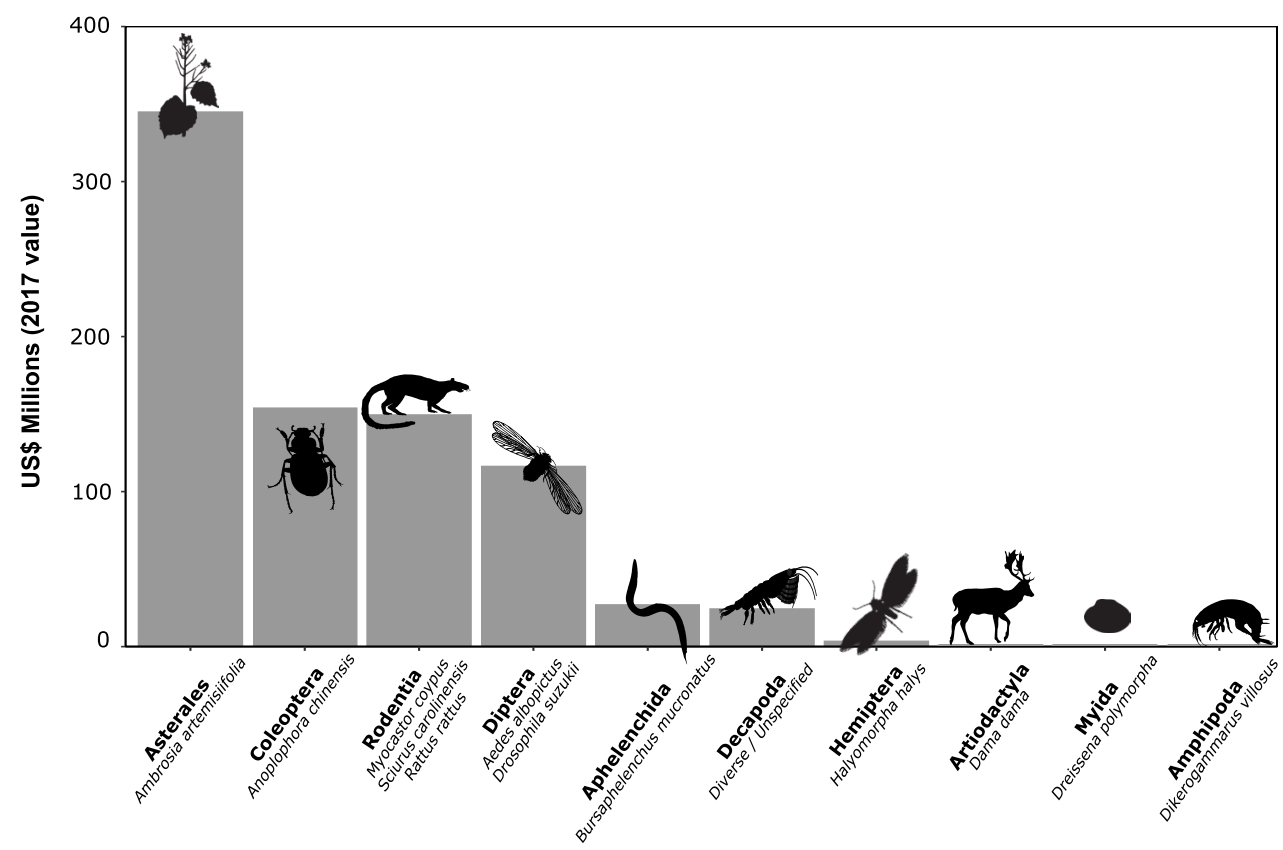

Figure I. Total costs generated by invasive alien species in Italy between 1990 and 2020 (in US\$ millions). Bold names on the $\mathrm{x}$-axis represent orders, while indicating species belonging to that class, as recorded in InvaCost.

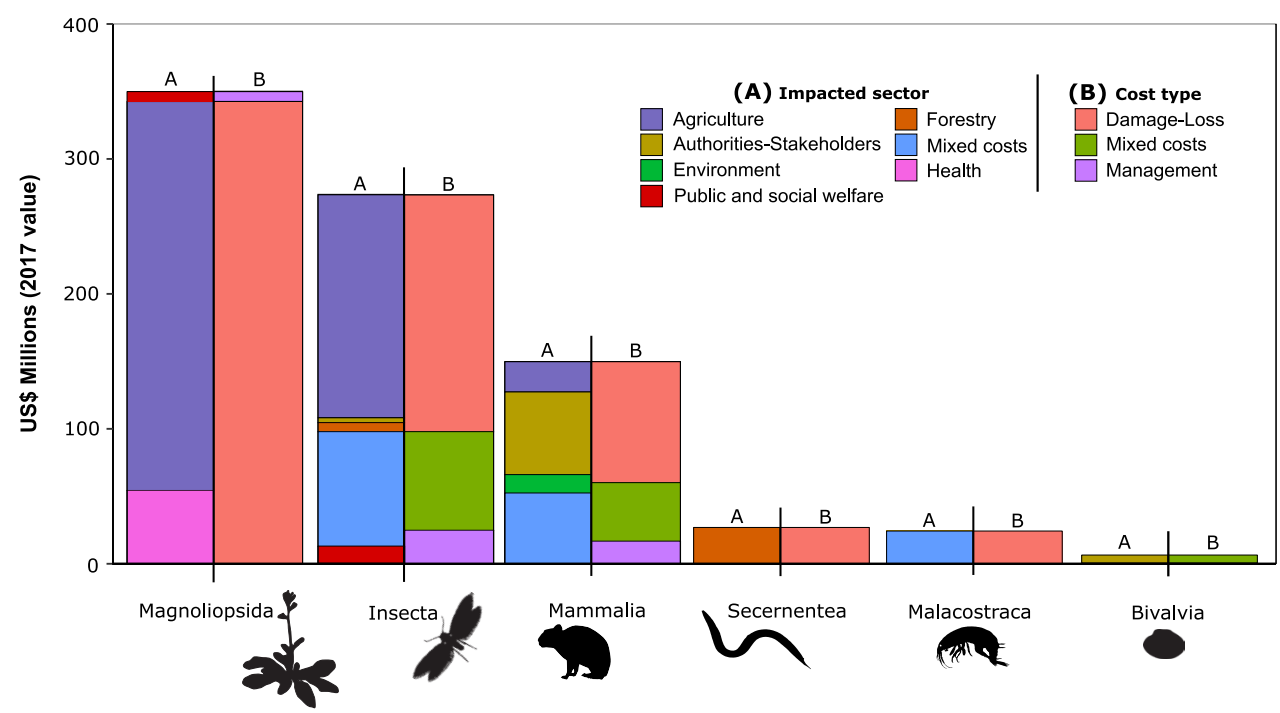

Figure 2. Total invasion costs estimates (in US\$ millions) in Italy between 1990 and 2020 according to cost types and impacted sectors according to the species classes.

health costs (US\$ 54.32 million; $\mathrm{n}=3$ ), forestry (US\$ 33.61 million; $\mathrm{n}=17$ ), authorities-stakeholders (i.e. all management policies, US\$ 6.31 million; $\mathrm{n}=19$ entries) and public and social welfare (US\$ 14.97 million; $\mathrm{n}=12$ ). Aquatic costs were only 


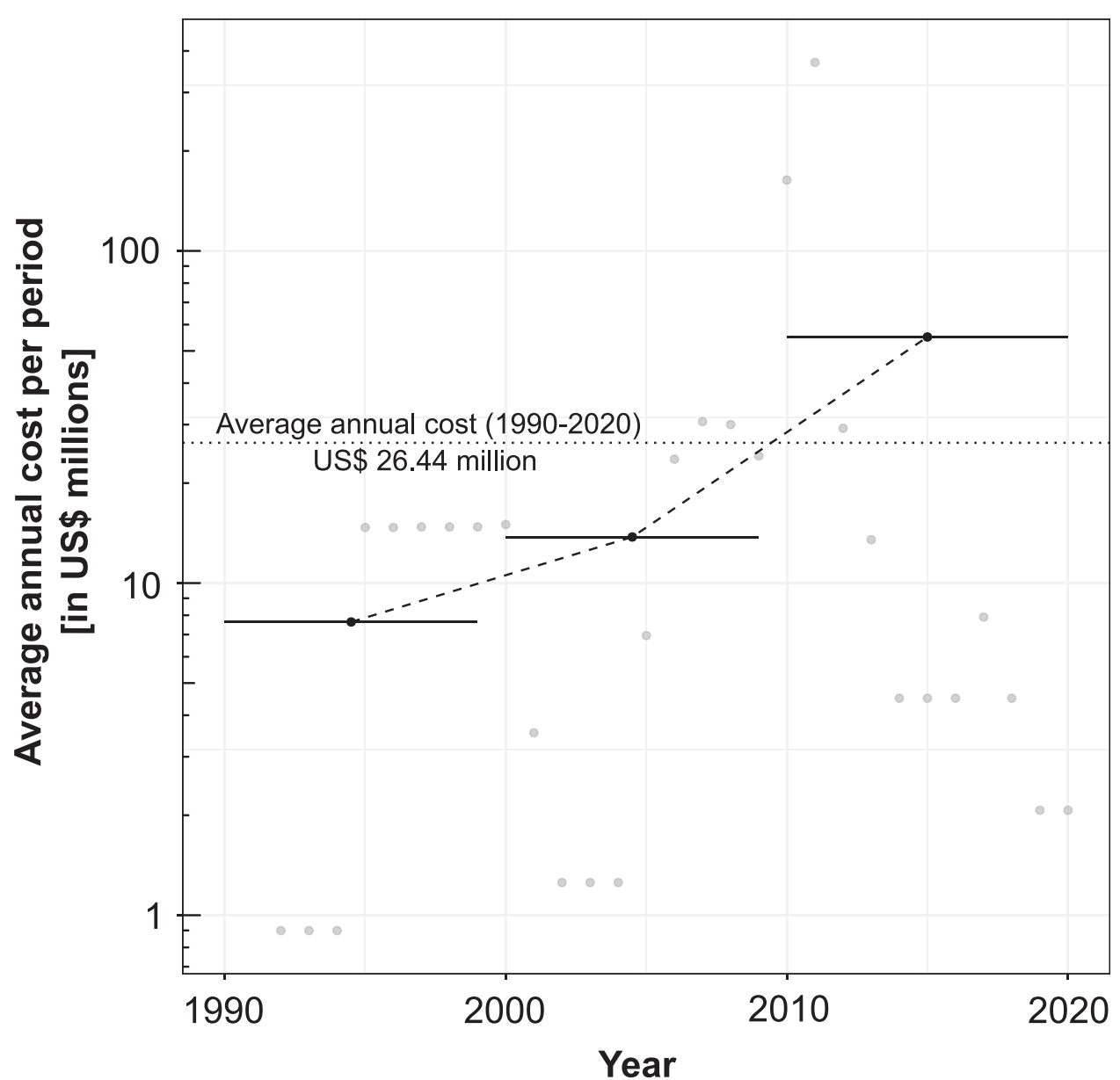

Figure 3. Average costs between 1990 and 2020 of invasive species in Italy. Bars represent decadal means and grey points indicate annual cost totals, whilst the dotted line illustrates the mean cost over the entire period. Note that the $y$-axis is on a log scale.

related to mixed sectors (US\$ 24.27 million; $\mathrm{n}=27$ ) or to authorities and stakeholders (US\$ 547.21 thousand; $\mathrm{n}=17)$ and were mostly incurred by decapods $(>99 \%)$ and marginally by amphipods $(<1 \%)$. Semi-aquatic costs were mostly incurred by authorities-stakeholders (US\$ 58.51 million; $\mathrm{n}=33$ ), followed by mixed sectors (US\$ 52.36 million; $n=9$ ), agriculture (US\$22.48 million; $\mathrm{n}=32$ ) and costs inferred to the environment (US\$ 13.72 million; $n=6$; Fig. 3). The Insecta class drove primarily costs to agricultural (US\$ 165.59 million) and mixed sectors (US\$ 84.89 million), while Magnoliopsida drove costs associated with agriculture mostly (US\$288.20 million). The single Secernentea reported cost impacted forestry (US\$ 26.91 million).

Damage and losses dominated by far (US\$ 659.07 million; $\mathrm{n}=110$ ), followed by management costs (US\$116.91 million; $\mathrm{n}=68$ ). Mixed type costs contributed a further US\$ 43.78 million $(n=29)$. The division of cost types within terrestrial 
habitats was as follows: US\$ 544.94 million for resource damages and losses $(\mathrm{n}=25$ entries), US\$ 75.85 million for control interventions ( $\mathrm{n}=30$ entries), and US\$27.09 million for mixed costs $(n=28)$ (Fig. 2). Costs associated with aquatic environments were mostly inferred from damage-losses (US\$ 24.25 million, $n=33$ ), with low management costs (US\$ 368.38 thousand; $\mathrm{n}=11$ ). Similarly, cost types in semi-aquatic habitats comprised resource damage and losses (US\$ 89.68 million; $\mathrm{n}=52$ entries), control interventions (US\$ 40.69 million; $\mathrm{n}=27$ entries) and mixed costs (US\$ 16.69 million; $\mathrm{n}=1$ entry).

\section{Economic costs by geographical region}

For several publications within the database, specific information about the region where the cost actually occurred was provided. This indicated a difference in economic cost data between the north and the south of Italy. Regional information was present only for northern/central regions, which included Emilia-Romagna (US\$ 99.05 million; $\mathrm{n}=27$ ), Latium (US\$ 24.27 million; $\mathrm{n}=27$ ), Trentino (US\$ 20.27 million; $\mathrm{n}=7$ ), Lombardia (US\$10.45 million; $\mathrm{n}=14$ ), Piedmont (US\$ 762.63 thousand; $\mathrm{n}=15$ ), Tuscany (US\$ 547.21 thousand; $\mathrm{n}=17$ ), and Umbria (US\$22.33 thousand; $\mathrm{n}=1$ ). From southern regions, only Sicily had reported costs (US\$ 6.70 million; $\mathrm{n}=4)$. Accordingly, there was a distinct lack of cost estimation concerning States in southern Italy. The other entries were given either at national level (US\$84.83 million; $\mathrm{n}=40$ ) or from unspecified locations (US\$572.85 million; $\mathrm{n}=55$ ).

\section{Temporal accumulation of costs}

The recorded average annual cost between 1990 and 2020 amounted to an average US\$2 6.44 million, with an exponential increase in decadal means over time (Fig. 3; note the $y$-axis is $\log _{10}$-transformed). In the most recent years, recorded costs of invasions in Italy have surpassed US\$ 50 million per year.

\section{Discussion}

The overall cost of invasive species in Italy has been estimated at US\$819.76 million ( $€$ 704.78 million) between 1990 and 2020. This can be seen as a conservative total cost (Diagne et al. 2021) and is most likely an underestimate of the actual costs, especially as costs have been occurring for several decades prior to the first Italian record and because very few known invasive taxa have reported costs. Indeed, many species or invasions have not been studied for their economic impact and many of those that have been studied are not publicly available (e.g. governmental reports, grey literature) and costs present therein were thus not recorded in the InvaCost database. Furthermore, it should be noted that some types of costs are simply difficult to quantify, especially regarding ecosystem services or damages and losses (Spangenberg and Settele 2010). The lack of such data is critical because it can give the false impression that costs due 
to invasive species are lower than they actually are. Consequently, due to a lack of synthesis of cost information from multiple sources, as well as disparate reporting amongst invasive taxa and invaded regions, decision-makers may not have the necessary information to evaluate the costs and benefits of invasive species management actions. As a result, this limits rationale to invest in preventative or control measures to reduce or manage invasions. However, while we acknowledge that the InvaCost database does not capture all available costs through the systematic searches employed, our data indicate that the economic costs of invasions and studies are growing exponentially over time and are unlikely to saturate soon.

Taxonomic, habitat and regional biases across current literature are prevalent, resulting in only a subset of invasions being evaluated. For example, to our knowledge, costs associated with phytosanitary inspections are not available. Moreover, several aquatic invasive species which are known to damage Italian freshwater ecosystems (e.g. freshwater crayfish) were only anecdotally recorded in the database without identifiable species, given a distinct lack of cost estimation. Additionally, impacts associated with invasive crayfish species, such as levee damaging burrowing behaviour (Haubrock et al. 2019), habitat engineering (Barbaresi et al. 2004), in addition to direct impact on native biodiversity (Gherardi and Acquistapace 2007), were not present in the InvaCost database. This may be due to the cultural and financial benefits of introductions outweighing potential economic cost or the nature of ecological impact, leading to nonvalue costs, which are inherently harder to estimate (e.g. native community changes, ecosystems changes) and, therefore, not reported.

Despite the number of invasive species in Italy exceeding 3000 (Gherardi et al. 2008; Pagad et al. 2018; National Database on Alien Species, ISPRA), the recorded costs of invasive species in Italy concerned only very few species. For example, fish were totally missing, despite known invasions and costs. In addition, reported costs in Italy were lower than in many other EU countries (Haubrock et al. 2021b). Indeed, national-scale costs were an order of magnitude higher in the UK (Cuthbert et al. 2021a), Germany (Haubrock et al. 2021c), France (Renault et al. 2021) and Spain (Angulo et al. 2021b). This could reflect the insufficient investment by the Italian public services into the surveillance and management of these species (i.e. via control, monitoring) relative to the direct impact cost on health and crops (i.e. health care, damage cost), as well as non-market values linked to biodiversity, ecosystem services, well-being or cultural benefits (Plieninger et al. 2013). Our results also show that the highest incurred costs are linked to the control of insects. It does not mean that invasive alien insects are more frequent in Italy, but only that these are seen by public authorities as a priority to limit the damage to agriculture and forestry and the risk of emerging vector- borne human diseases, such as yellow fever, Zika, dengue or chikungunya, which are pathogens vectored principally by Aedes aegypti and Ae. albopictus (Beltrame et al. 2007; Zammarchi et al. 2015). Damage-losses through mammals (i.e. rodents) played only a subordinate role compared to insects. This could be due to several factors, such as lack of dedicated funds and coordinated and continuous control plans, public perception against the control of mammals (especially for squirrels and even for coypu) and problems with legislation (i.e. before EU Regulation 1143/2014, the change of 
juridical status of the coypu caused a decrease in control actions). Yet, amidst the noted lack of reported costs for insects and mammals, these taxonomic groups may present the complete records amongst all recorded groups.

Nevertheless, the lack of information on invasion-related costs could be due to the search terms used to identify economic cost literature when building InvaCost or to the lack of specific data available. For instance, a search in Italian, using a different search string including species names that are known to cause damage in Italy, yielded two additional cost estimations (as included in our data analysis). This highlights the existence, but restricted availability of important information, as (1) in the Region of Latium, central Italy, economic impacts of alien crayfish species were estimated between $€ 140,000$ and 1.17 million per year, including damage to angling, aquaculture and agriculture (Gherardi et al. 2014); (2) in the Region of Piedmont, damage in rice fields due to burrowing activities of Procambarus clarkii led to a decrease of $6 \%$ in the annual rice production, while in 'Consorzio di Bonifica dell'Emilia Centrale' $€ 1000$ per $\mathrm{m}^{2}$ was necessary to rebuild levees damaged by its burrowing activity (Gherardi et al. 2014). Similarly, damage caused to agriculture by coypu was estimated at around $€ 1$ million, while damage and restoration of levees incurred costs of nearly $€ 11$ million (Panzacchi et al. 2007).

Regionally, economic costs of invasive alien species were reportedly higher in the north of Italy (North: US\$ 155.37 million; South: US\$ 6.70 million). Regions in northern Italy are commonly associated with higher population densities and human activities (Gherardi et al. 2008). Northern Italy also belongs to a different climatic zone (Grapow and Blasi 1998; Celesti-Grapow et al. 2010). It is, however, difficult to be confident that these observed regional cost differences reflect true differences in governance or monetised impacts, rather than a discrepancy in reporting costs between northern and southern regions. That is due to the fact that reporting of costs can be described as limited, considering that only 15 invasive species had recorded costs. Further, a considerable share of the total costs $(-80 \%)$ was not clearly distinguishable for any region, with this low resolution negating a more comprehensive regional analysis. However, extensive/intensive agriculture (CREA 2017) and drainage basins (Gherardi et al. 2008) are concentrated in the north, potentially explaining part of the bias in reported economic costs that were available in InvaCost. As a result, the described lack of aquatic costs entries in the north is a cause for concern, as the numbers of invasive species and affected freshwater ecosystems are relatively high in the north of Italy, indicating a severe neglect of invasive aquatic species costs for Italy overall. The overall bias towards costs on terrestrial habitats and the scarcity of information regarding aquatic habitats could be explained by the nature of the damaged economic sectors with terrestrial ecosystems being more commonly perceived, leading to more public awareness amongst populations. This trend also reflects that on the global scale, whereby aquatic species invasion costs have been underreported compared to terrestrial taxa, relative to known numbers of alien species between those habitat types (Cuthbert et al. 2021b). Additionally, Italy has a long history of active species introduction into freshwater ecosystems. Amongst species like the red swamp crayfish P. clarkii (Gherardi 
and Acquistapace 2007) or the pond slider Trachemys scripta (Ficetola and Scali 2010), a very well-known example is the black bullhead Ameiurus melas, which first appeared in 1904 (Tortonese 1970) and has now spread throughout Italy, reaching high densities in, for example, the River Tiber and the Corbara Reservoir (Pedicillo et al. 2008). The key drivers for these introductions have often been cultural, because the introduction of alien freshwater species is often perceived as favourable and beneficial for local municipalities (Selge et al. 2011; Kilian et al. 2012), as it increases the attraction of fisheries, for example, for recreational angling. Therefore, in future studies, it would be important to address the costs of invasions for the economy, whilst considering potential values, particularly in terms of angling.

In addition, we identified an exponential increase in costs through time since 1990 , with annual average cost exceeding US\$ 50 million in recent years. Given that the US\$ 819.76 million total is attributed to only 15 out of the more than 3,000 known alien species in Italy (Pagad et al. 2018; National Database on Alien Species, ISPRA) and probably far from exhaustively for these 15 species (see above), it can be easily appreciated how significantly underestimated this overall cost is, regardless of how they are representative of these few species. For instance, only one database entry referred to the grey squirrel (Sciurus carolinensis), which has been studied and managed thoroughly in Italy (Genovesi and Bertolino 2001; Martinoli et al. 2010) and no entries regarded the well-investigated costs from the impacts of invasive crayfish were found (Gherardi et al. 2014). Further, the costs of management activities in Italy spent solely on IAS within the Union Concern list of EU Regulation 1143/2014, between 2016 and 2018 (in total 48 listed species for this period, 31 of which are present in Italy and 20 that were managed between 2016 and 2018), were estimated at EU€1.85 million ( - US\$2.17 million) for those two years (Alonzi et al. 2020). Annually, this figure suggests that the monetary investments into management efforts were between 24-times (considering the entire period) and 46-times (considering only the two recent years) lower than the total costs inferred by IAS at the national level. However, it should be noted that (i) today, 42 of the now 66 IAS listed are present in Italy and, (ii) this cost does not consider the allocated funds for IAS at regional levels. As a result, the actual, unreported or unevaluated economic costs of all IAS in Italy must be staggering.

In conclusion, the presented economic costs of biological invasions in Italy will contribute to informed decision-making at the national level and, thus, providing economic incentives for mitigating the arrival, spread and damage of invasive species. The relatively-high costs reported for Italy, despite the low number of entries in the database contrasting with the high number of invasive species, underlines the need for prevention and surveillance programmes, as costs spent on these are generally considered several magnitudes lower than active management (Leung et al. 2002). Our study highlights the need for national and regional authorities to produce more structured reporting of costs in order to refine these figures further (Diagne et al. 2020b, 2021). However, future perspectives indicate an urgently-needed increase in national budgets to tackle the threat of alien species (Silva et al. 2014; OECD 2019). Further studies are 
also required to examine costs attributed to invasive species in other EU countries, as these may facilitate better-coordinated international actions and drive policy change to mitigate economic costs of invasive species. Nevertheless, we highlighted the increase in annual costs for Italy: the numbers of invasions will increase over time (Seebens et al. 2017) and, thus, it is most likely that reported costs will continue to rapidly increase during the coming decades.

\section{Acknowledgement}

The authors acknowledge the French National Research Agency (ANR-14-CE02-0021) and the BNP-Paribas Foundation Climate Initiative for funding the InvaCost project that allowed the construction of the InvaCost database. The present work was conducted following a workshop funded by the AXA Research Fund Chair of Invasion Biology and is part of the AlienScenario project funded by BiodivERsA and Belmont-Forum call 2018 on biodiversity scenarios. RNC is funded through a research fellowship from the Alexander von Humboldt Foundation. CD is funded by the BiodivERsA-Belmont Forum Project "Alien Scenarios" (BMBF/PT DLR 01LC1807C).

\section{References}

Angulo E, Diagne C, Ballesteros-Mejía L, Akulov EN, Dia CAKM, Adamjy T, Banerjee A-K, Capinha C, Duboscq VG, Dobigny G, Golivets M, Heringer G, Haubrock PJ, Kirichenko N, Kourantidou M, Liu C, Nuñez M, Renault D, Roiz D, Taheri A, Watari Y, Xiong W, Courchamp F (2021a) Non-English languages enrich scientific data: the example of thecosts of biological invasions. Science of the Total Environment 775: e144441. https://doi. org/10.1016/j.scitotenv.2020.144441

Angulo E, Ballesteros-Mejia L, Novoa A, Duboscq-Carra VG, Diagne C, Courchamp F (2021) Economic costs of invasive alien species in Spain. In: Zenni RD, McDermott S, GarcíaBerthou E, Essl F (Eds) The economic costs of biological invasions around the world. NeoBiota 67: 267-297. https://doi.org/10.3897/neobiota.67.59181

Alonzi A, Aragno P, Carnevali L, Grignetti A, Genovesi P (2020) Prima rendicontazione nazionale ai sensi dell'art. 24 del Reg. (UE) n. 1143/2014 sulle specie esotiche invasive (20162018). Rapporto tecnico.

Barbaresi S, Tricarico E, Gherardi F (2004) Factors inducing the intense burrowing activity of the red-swamp crayfish, Procambarus clarkii, an invasive species. Naturwissenschaften 91: 342-345. https://doi.org/10.1007/s00114-004-0533-9

Bellard C, Cassey P, Blackburn TM (2016) Alien species as a driver of recent extinctions. Biology Letters 12: e20150623. https://doi.org/10.1098/rsbl.2015.0623

Beltrame A, Angheben A, Bisoffi Z, Monteiro G, Marocco S, Calleri G, Gulletta M (2007) Imported chikungunya infection, Italy. Emerging Infectious Diseases 13: e1264. https:// doi.org/10.3201/eid1308.070161 
Bradshaw CJA, Leroy B, Bellard C, Roiz D, Albert C, Fournier A, Barbet-Massin M, Salles JM, Simard F, Courchamp F (2016) Massive yet grossly underestimated global costs of invasive insects. Nature Communications 7: e12986. https://doi.org/10.1038/ncomms12986

Castaldelli G, Pluchinotta A, Milardi M, Lanzoni M, Giari L, Rossi R, Fano EA (2013) Introduction of exotic fish species and decline of native species in the lower Po basin north-eastern Italy. Aquatic Conservation: Marine and Freshwater Ecosystems 23: 405-417. https:// doi.org/10.1002/aqc.2345

Celesti-Grapow L, Alessandrini A, Arrigoni PV, Assini S, Banfi E, Barni E, Carli E (2010) Nonnative flora of Italy: Species distribution and threats. Plant Biosystems 144: 12-28. https:// doi.org/10.1080/11263500903431870

CREA [Centro di ricerca Politiche e Bioeconomia] (2017) Italian agriculture in figures 2017; Rome 2018.

Cuthbert RN, Bacher S, Blackburn TM, Briski E, Diagne C, Dick JT, Haubrock PJ, Lenzner B, Courchamp F (2020) Invasion costs impacts and human agency: Response to Sagoff 2020. Conservation Biology 34: 1579-1582. https://doi.org/10.1111/cobi.13592

Cuthbert RN, Bartlett AC, Turbelin AJ, Haubrock PJ, Diagne C, Pattison Z, Courchamp F, Catford JA (2021) Economic costs of biological invasions in the United Kingdom. In: Zenni RD, McDermott S, García-Berthou E, Essl F (Eds) The economic costs of biological invasions around the world. NeoBiota 67: 299-328. https://doi.org/10.3897/neobiota.67.59743

Cuthbert RN, Pattison Z, Taylor NG, Verbrugge L, Diagne C, Ahmed DA, Leroy B, Angulo E, Briski E, Capinha C, Catford JA, Dalu T, Essl F, Gozlan RE, Haubrock PJ, Kourantidou M, Kramer AM, Renault D, Wasserman RJ, Courchamp F (2021b) Global economic costs of aquatic invasive alien species. Science of the Total Environment 775: e145238. https:// doi.org/10.1016/j.scitotenv.2021.145238

Diagne C, Catford J, Essl F, Nuñez M, Courchamp F (2020a) What are the economic costs of biological invasions? A complex topic requiring international and interdisciplinary expertise. NeoBiota 63: 1-25. https://doi.org/10.3897/neobiota.63.55260

Diagne C, Leroy B, Gozlan RE, Vaissiere AC, Assailly C, Nuninger L, Roiz D, Jourdain F, Jarić I, Courchamp F (2020b) INVACOST: a public database of the economic costs of biological invasions worldwide. Scientific Data: 2020. https://doi.org/10.1038/s41597-020-00586-z

Diagne C, Leroy B, Vaissière A-C, Gozlan RE, Roiz D, Jarić I, Salles JM, Bradshaw CJA, Courchamp F (2021) High and rising economic costs of biological invasions worldwide. Nature 592: 571-576. https://doi.org/10.1038/s41586-021-03405-6

Dick JT, Laverty C, Lennon JJ, Barrios-O’Neill D, Mensink PJ, Britton JR, Dunn AM (2017) Invader Relative Impact Potential: a new metric to understand and predict the ecological impacts of existing emerging and future invasive alien species, Journal of Applied Ecology 54(4): 1259-1267. https://doi.org/10.1111/1365-2664.12849

Didham RK, Tylianakis JM, Hutchison MA, Ewers RM, Gemmell NJ, (2005) Are invasive species the drivers of ecological change?. Trends in Ecology \& Evolution 20: 470-474. https:// doi.org/10.1016/j.tree.2005.07.006

Doherty TS, Glen AS, Nimmo DG, Ritchie EG, Dickman CR (2016) Invasive predators and global biodiversity loss. Proceedings of the National Academy of Sciences of the United States of America 113: 11261-11265. https://doi.org/10.1073/pnas.1602480113 
Ficetola GF, Scali S (2010) Invasive amphibians and reptiles in Italy. In Atti VIII Congresso Nazionale Societas Herpetologica Italica. Ianieri Edizioni, Pescara, 335-340.

Genovesi P, Bertolino S (2001) Human dimension aspects in invasive alien species issues: the case of the failure of the grey squirrel eradication project in Italy, The great reshuffling: human dimensions of invasive alien species. IUCN Gland, 113-119.

Gherardi F, Aquiloni L, Bertocchi S, Brusconi S, Inghilesi AI, Mazza G, Scalici M, Tricarico E (2014) Un contributo multidisciplinare alla conoscenza dei gamberi alloctoni del Lazio. In: Monaco A (a cura di) Alieni: la minaccia delle specie alloctone per la biodiversità del Lazio, Palombi editori, Roma, 116-135.

Gherardi F, Acquistapace P (2007) Invasive crayfish in Europe: the impact of Procambarus clarkii on the littoral community of a Mediterranean lake. Freshwater Biology 52: 12491259. https://doi.org/10.1111/j.1365-2427.2007.01760.x

Gherardi F, Bertolino S, Bodon M, Casellato S, Cianfanelli S, Ferraguti M, Rossetti G (2008) Animal xenodiversity in Italian inland waters: distribution modes of arrival and pathways. Biological Invasions 10: 435-454. https://doi.org/10.1007/s10530-007-9142-9

Grapow L, Blasi C (1998) A comparison of the urban flora of different phytoclimatic regions in Italy. Global Ecology \& Biogeography Letters 7: 367-378. https://doi. org/10.2307/2997684

Gravili C, Belmonte G, Cecere E, Denitto F, Giangrande A, Guidetti P, Piraino S (2010) Nonindigenous species along the Apulian coast Italy. Chemistry and Ecology 26: 121-142. https://doi.org/10.1080/02757541003627654

Gren M, Isacs L, Carlsson M (2009) Costs of alien invasive species in Sweden. AMBIO: A Journal of the Human Environment 38: 135-141. https://doi.org/10.1579/0044-7447-38.3.135

Guichón ML, Benitez VB, Abba A, Borgnia M, Cassini MH (2003) Foraging behaviour of coypus Myocastor coypus: why do coypus consume aquatic plants?. Acta Oecologica 24: 241-246. https://doi.org/10.1016/j.actao.2003.08.001

Gurevitch J, Padilla DK (2004) Are invasive species a major cause of extinctions? Trends in Ecology \& Evolution 19: 470-474. https://doi.org/10.1016/j.tree.2004.07.005

Haubrock PJ, Inghilesi AF, Mazza G, Bendoni M, Solari L, Tricarico E (2019) Burrowing activity of Procambarus clarkii on levees: analysing behaviour and burrow structure. Wetlands Ecology and Management 27: 497-511. https://doi.org/10.1007/s11273-019-09674-3

Haubrock PJ, Pilotto F, Innocenti G, Cianfanelli S, Haase P (2021a) Two centuries for an almost complete community turnover from native to non-native species in a riverine ecosystem. Global Change Biology 27(3): 606-623. https://doi.org/10.1111/gcb.15442

Haubrock PJ, Turbelin AJ, Cuthbert RN, Novoa A, Taylor NG, Angulo E, Ballesteros-Mejia L, Bodey TW, Capinha C, Diagne C, Essl F, Golivets M, Kirichenko N, Kourantidou M, Leroy B, Renault D, Verbrugge L, Courchamp F (2020) Economic costs of invasive alien species across Europe In: Zenni RD, McDermott S, García-Berthou E, Essl F (Eds) The economic costs of biological invasions around the world. NeoBiota 67: 153-190. https:// doi.org/10.3897/neobiota.67.58196

Haubrock PJ, Cuthbert RN, Sundermann A, Diagne C, Golivets M, Courchamp F (2021) Economic costs of invasive species in Germany. In: Zenni RD, McDermott S, GarcíaBerthou E, Essl F (Eds) The economic costs of biological invasions around the world. NeoBiota 67: 225-246. https://doi.org/10.3897/neobiota.67.59502 
Hensley MP (2012) A critique on the current standards for evaluating costs for invasive species in economic literature. In: Holmes TP, Aukema JE, Von Holle B, Liebhold A, Sills E (Eds) Economic Impacts of Invasive Species in Forests Past, Present, and Future. Annals of the New York Academy of Sciences 1162: 18-38. https://doi.org/10.1111/j.1749-6632.2009.04446.x Holmes TP, Aukema JE, Von Holle B, Liebhold A, Sills E (2009) Economic impacts of invasive species in forest past, present, and future. The Year In Ecology and Conservation Biology. Annals of the New York Academy of Sciences 1162: 18-38. https://doi.org/10.1111/ j.1749-6632.2009.04446.x

Hulme PE, Pyšek P, Nentwig W, Vilà M (2009) Will threat of biological invasions unite the European Union? Science 324: 40-41. https://doi.org/10.1126/science.1171111

Inghilesi AF, Mazza G, Cervo R, Gherardi F, Sposimo P, Tricarico E, Zapparoli M (2013) Alien insects in Italy: comparing patterns from the regional to European level. Journal of Insect Science 13(1): e73. https://doi.org/10.1673/031.013.7301

James H, O'Rourke KH (2011) Italy and the first age of Globalization 1861-1940. Bank of Italy Economic History Working Paper 16 [39 pp.]. https://doi.org/10.2139/ssrn.2238016

Kettunen M, Genovesi P, Gollasch S, Pagad S, Starfinger U, ten Brink P, Shine C (2009) Technical support to EU strategy on invasive alien species (IAS) Institute for European Environmental Policy (IEEP) Brussels 44.

Kilian JV, Klauda RJ, Widman S, Kashiwagi M, Bourquin R, Weglein S, Schuster J (2012) An assessment of a bait industry and angler behavior as a vector of invasive species. Biological Invasions 14: 1469-1481. https://doi.org/10.1007/s10530-012-0173-5

Leroy B, Kramer AM, Vaissière AC, Courchamp F, Diagne C (2020) Analysing global economic costs of invasive alien species with the invacost $\mathrm{R}$ package. bioRxiv. https://doi. org/10.1101/2020.12.10.419432

Leung B, Lodge DM, Finnoff D, Shogren JF, Lewis MA, Lamberti G (2002) An ounce of prevention or a pound of cure: bioeconomic risk analysis of invasive species, Proceedings of the Royal Society of London Series B: Biological Sciences 269: 2407-2413. https://doi. org/10.1098/rspb.2002.2179

Lovell SJ, Stone SF, Fernandez L (2006) The economic impacts of aquatic invasive species: a review of the literature. Agricultural and Resource Economics Review 35: 195-208. https:// doi.org/10.1017/S1068280500010157

Malcolm JR, Markham A (2000) Global warming and terrestrial biodiversity decline. Washington DC: WWF.

Marbuah G, Gren IM, McKie B (2014) Economics of harmful invasive species: a review. Diversity 6: 500-523. https://doi.org/10.3390/d6030500

Martinoli A, Bertolino S, Preatoni DG, Balduzzi A, Marsan A, Genovesi P, Wauters LA (2010) Headcount 2010: the multiplication of the grey squirrel populations introduced to Italy. Hystrix the Italian Journal of Mammalogy 21.

Nunes AL, Katsanevakis S, Zenetos A, Cardoso AC (2014) Gateways to alien invasions in the European seas, Aquatic Invasions 9: 133-144. https://doi.org/10.3391/ai.2014.9.2.02

Nunes AL, Tricarico E, Panov V, Katsanevakis S, Cardoso AC (2015) Pathways and gateways of freshwater invasions in Europe. Aquatic Invasions 10: 359-370. https://doi.org/10.3391/ ai.2015.10.4.01 
Occhipinti-Ambrogi AO (2002) Current status of aquatic introductions in Italy. In: Invasive aquatic species of Europe, Distribution impacts and management. Springer Dordrecht, 311-324. https://doi.org/10.1007/978-94-015-9956-6_32

Occhipinti-Ambrogi A, Marchini A, Cantone G, Castelli A, Chimenz C, Cormaci M, Giangrande A (2011) Alien species along the Italian coasts: an overview. Biological Invasions 13: 215-237. https://doi.org/10.1007/s10530-010-9803-y

OECD (2019) Biodiversity: Finance and the Economic and Business Case for Action report prepared for the G7 Environment Ministers' Meeting 5-6 May 2019.

Pagad S, Genovesi P, Carnevali L, Schigel D, McGeoch MA (2018) Introducing the global register of introduced and invasive species. Scientific Data 5: e170202. https://doi. org/10.1038/sdata.2017.202

Panzacchi M, Cocchi R, Genovesi P, Bertolino S (2007) Population control of coypu Myocastor coypus in Italy compared to eradication in UK: a cost-benefit analysis. Wildlife Biology 13: 159-171. https://doi.org/10.2981/0909-6396(2007)13[159:PCOCMC]2.0.CO;2

Pedicillo G, Bicchi A, Angeli V, Carosi A, Viali P, Lorenzoni M (2008) Growth of black bullhead Ameiurus melas (Rafinesque, 1820) in Corbara Reservoir (Umbria-Italy). Knowledge and Management of Aquatic Ecosystems 389: e05. https://doi.org/10.1051/kmae/2008011

Perrings C (2011) Elton and the economics of biological invasions. In Fifty Years of Invasion Ecology: The Legacy of Charles Elton, Blackwell Oxford. https://doi. org/10.1002/9781444329988.ch24

Pimentel D, Lach RZ, Morrison D (2000) Environmental and economic costs of nonindigenous species in the United States. Bioscience 50: 53-65. https://doi.org/10.1641/00063568(2000)050[0053:EAECON]2.3.CO;2

Pimentel D, Zuniga R, Morrison D (2005) Update on the environmental and economic costs associated with alien-invasive species in the United States. Ecological Economics 52(3): 273-288. https://doi.org/10.1016/j.ecolecon.2004.10.002

Plieninger T, Dijks S, Oteros-Rozas E, Bieling C (2013) Assessing mapping and quantifying cultural ecosystem services at community level. Land Use Policy 33: 118-129. https://doi. org/10.1016/j.landusepol.2012.12.013

Reba M, Reitsma F, Seto KC (2016) Spatializing 6,000 years of global urbanization from 3700 BC to AD 2000. Scientific Data 3: 1-16. https://doi.org/10.1038/sdata.2016.34

Renault D, Manfrini E, Leroy B, Diagne C, Ballesteros-Mejia L, Angulo E, Courchamp F (2021) Biological invasions in France: Alarming costs and even more alarming knowledge gaps. In: Zenni RD, McDermott S, García-Berthou E, Essl F (Eds) The economic costs of biological invasions around the world. NeoBiota 67: 191-224. https://doi.org/10.3897/neobiota.67.59134

Seebens H, Blackburn TM, Dyer EE, Genovesi P, Hulme PE, Jeschke JM, Bacher S (2017) No saturation in the accumulation of alien species worldwide. Nature Communications 8: e14435. https://doi.org/10.1038/ncomms14435

Selge S, Fischer A, van der Wal R (2011) Public and professional views on invasive alien species-A qualitative social scientific investigation. Biological Conservation 144: 3089-3097. https://doi.org/10.1016/j.biocon.2011.09.014 
Scalera R (2010) How much is Europe spending on invasive alien species? Biological Invasions 12: 173-177. https://doi.org/10.1007/s10530-009-9440-5

Silva JP, Sopeña A, Sliva J, Toland J, Nottingham S, Jones W, Eldridge, J Thorpe E, Thévignot C, Salsi A (2014) LIFE and invasive alien species, Publications Office of the European Union Luxembourg.

Spangenberg JH, Settele J (2019) Precisely incorrect? Monetising the value of ecosystem services. Ecological Complexity 7: 327-337. https://doi.org/10.1016/j.ecocom.2010.04.007

Stigall AL (2010) Invasive species and biodiversity crises: testing the link in the Late Devonian. PLoS ONE 5: e15584. https://doi.org/10.1371/journal.pone.0015584

Tortonese E (1970) Osteichthyes (Pesci Ossei) I, Fauna Ittica 10: 1-565.

Tricarico E, Inghilesi AF, Brundu G, Liriti G, Loi MC, Monaco A (2018) Le specie aliene invasive: Cosa e come comunicare al grande pubblico - Guida tecnica per operatori didattici di orti botanici zoo musei scientifici acquari e aree protette. LIFE ASAP ISBN: 978-88943544-0-9.

Vilà M, Espinar JL, Hejda M, Hulme PE, Jarošík V, Maron JL, Pergl J, Schaffner U, Sun Y, Pyšek P (2011) Ecological impacts of invasive alien plants: A meta-analysis of their effects on species, communities and ecosystems. Ecology Letters 14: 702-708. https://doi. org/10.1111/j.1461-0248.2011.01628.x

Zammarchi L, Stella G, Mantella A, Bartolozzi D, Tappe D, Günther S, Schmidt-Chanasit J (2015) Zika virus infections imported to Italy: clinical immunological and virological findings and public health implications. Journal of Clinical Virology 63: 32-35. https://doi. org/10.1016/j.jcv.2014.12.005

\section{Supplementary material I}

\section{Data used for the estimation of invasive species costs in Italy}

Authors: Phillip J. Haubrock, Ross N. Cuthbert, Elena Tricarico, Christophe Diagne, Franck Courchamp, Rodolphe E. Gozlan

Data type: cost data

Explanation note: This table contains collected information for invasive species recorded in Italy as listed in the InvaCost database.

Copyright notice: This dataset is made available under the Open Database License (http://opendatacommons.org/licenses/odbl/1.0/). The Open Database License $(\mathrm{ODbL})$ is a license agreement intended to allow users to freely share, modify, and use this Dataset while maintaining this same freedom for others, provided that the original source and author(s) are credited.

Link: https://doi.org/10.3897/neobiota.67.57747.suppl1 


\section{Supplementary material 2}

\section{Description of the Impacted Sector categories}

Authors: Christophe Diagne, Franck Courchamp

Data type: classification

Explanation note: This table contains the information on impacted sector reclassification as practiced for this manuscript.

Copyright notice: This dataset is made available under the Open Database License (http://opendatacommons.org/licenses/odbl/1.0/). The Open Database License $(\mathrm{ODbL})$ is a license agreement intended to allow users to freely share, modify, and use this Dataset while maintaining this same freedom for others, provided that the original source and author(s) are credited.

Link: https://doi.org/10.3897/neobiota.67.57747.suppl2

\section{Supplementary material 3}

\section{Number of recorded studies over the cumulative estimates}

Authors: Phillip J. Haubrock, Ross N. Cuthbert

Data type: figure, trend

Explanation note: Estimation of the relationship between recorded studies and cumulative estimates from the Italian InvaCost datasubset.

Copyright notice: This dataset is made available under the Open Database License (http://opendatacommons.org/licenses/odbl/1.0/). The Open Database License $(\mathrm{ODbL})$ is a license agreement intended to allow users to freely share, modify, and use this Dataset while maintaining this same freedom for others, provided that the original source and author(s) are credited.

Link: https://doi.org/10.3897/neobiota.67.57747.suppl3 